\title{
BMJ Paediatrics Open \\ COVID-19 and child marriage in Bangladesh: emergency call to action
}

\author{
Md. Jamal Hossain (1D , ${ }^{1}$ Mahfuza Afroz Soma, ${ }^{2}$ Md. Sazzadul Bari, ${ }^{1}$ \\ Talha Bin Emran (D), ${ }^{3}$ Md. Rabiul Islam ${ }^{2}$
}

To cite: Hossain MJ, Soma MA, Bari MS, et al. COVID-19 and child marriage in Bangladesh: emergency call to action. BMJ Paediatrics Open 2021;5:e001328. doi:10.1136/ bmjpo-2021-001328

Received 22 October 2021 Accepted 7 November 2021
Check for updates

(C) Author(s) (or their employer(s)) 2021. Re-use permitted under CC BY-NC. No commercial re-use. See rights and permissions. Published by BMJ.

${ }^{1}$ Department of Pharmacy, State University of Bangladesh, Dhaka Bangladesh

${ }^{2}$ Department of Pharmacy, University of Asia Pacific, Dhaka, Bangladesh

${ }^{3}$ Department of Pharmacy, BGC Trust University Bangladesh Chittagong, Bangladesh

Correspondence to Mr. Md. Jamal Hossain; jamal. du.p48@gmail.com

\section{ABSTRACT}

The social burden of Bangladesh's already prevalent child marriage problem has further flared up amid the ongoing COVID-19 pandemic. We aim to briefly report on the current scenario of underage marriage in Bangladesh from available sources and highlight concerns. The prevalence of child marriage has increased by at least $13 \%$ due to pandemic-enforced long-term school closure throughout the country, while many cases remain unreported. Exacerbated financial crisis, the prolonged shutdown of educational institutions and social insecurities are the principal triggering factors for such a high pace of child marriages. We urge the government and local administrations to address the current situation through concerted and integrated efforts to combat the early marriage crisis in Bangladesh.

Child marriage, especially involving female teenagers or adolescents to much older male counterparts, has been a long-standing socioeconomic crisis in Bangladesh with the highest rate in Asia and fourth highest globally. ${ }^{1}$ About $59 \%$ of women in the country aged 20-24 years were married before the age of 18 years. ${ }^{1}$ The current number of child brides is a staggering 38 million, while around 13 million of them have been forced into marriage even before 15 years of age. ${ }^{2}$ In the pre-COVID-19 era, Bangladesh had invested tremendous efforts in preventing child marriages. Subsequently, over the decade of 2007-2017, child marriages reduced nationally from $66 \%$ to $59 \%$, whereas marriage before 16 years of age plummeted from $46 \%$ to $32 \% .^{2}$ Despite the transient progress, thousands of child marriages are regularly occurring in the country, particularly in the rural and underdeveloped regions.

Child marriage cases have again gained momentum by increasing at least $13 \%$ over the past year in Bangladesh, coinciding with the COVID-19 pandemic. ${ }^{3}$ Due to a lack of country-wide surveillance or data gaps, we do not have the actual statistics of child marriage in Bangladesh. What we have are various media reports and non-government organisations' data collation about child marriage during the COVID-19 lockdown in Bangladesh. A survey conducted in 13 districts revealed that around 11000 early marriages occurred between 17 March 2020 and 12 September 2021. ${ }^{4}$ In contrast, Manusher Jonno Foundation has reported 13886 child marriages that happened from March to September of 2020 in 21 districts of Bangladesh. ${ }^{4}$ Along with the entire country, the most unfortunate incidents were reported from Rajshahi, Khulna, Kurigram and Bagerhat, with around 6500, 3000, 2950 and 3200 child marriage cases, respectively, during the last 18 months of the COVID-19 lockdown. ${ }^{245}$ Among the 103407 high school female students of the Rajshahi district, 6512 (around 6.3\%) were subjected to underage marriage during school closures, with the largest share $(n=1785 ; 27.4 \%)$ reported from Bagmara Upazila of the district. ${ }^{2}$

Since early 2020, there has been a dramatic upsurge in the prevalence of underage marriage, unintended pregnancies and genderbased violence in Bangladesh. ${ }^{6}$ Increased poverty, prolonged school closures, service interruptions, social security concerns, family honour, societal norms, customary or religious regulations, parental deaths, and other social and familial factors have all contributed to this unexpected upsurge in child marriages amid the current pandemic. Additionally, the institutional shutdown may encourage female students from financially challenged and backward families to drop out of school and never return. Evidence demonstrated that $71 \%$ of underage marriages in Bangladesh occurred due to the school closure amid the ongoing COVID-19 pandemic. ${ }^{1}$ Moreover, the loss of the regular income aggravated economic vulnerability, which resulted in an inclination towards low-cost marriage ceremonies to alleviate existing financial burdens.

Regarding the complete abolition of child marriage practice, the government of Bangladesh has been maintaining a resolute and unwavering commitment to meet the Sustainable Development Goal and the National Target 
by 2030 and 2041, respectively. Eventually, the government adopted several synchronous policies and implemented many actionable measures at root levels. However, the progress in curbing underage marriage has been substantially disrupted during the COVID-19 pandemic. Therefore, the government and its development partners, private sector stakeholders and relevant non-government organisations must step forward in a coalition to reanalyse the current scenario and undertake competitive initiatives to undermine the sudden outrage of this crisis.

Since institutional shutdowns have been contributing to educational discontinuation and subsequent enforcement of child marriages, respective institutional authorities, in assistance of other available social infrastructures, should reach out to the vulnerable families and establish regular communication with them to prevent any mishap from happening. Moreover, stringent enforcement of existing laws must be ensured by local administration to combat child marriage and its adverse impacts. The government should also concentrate on developing sturdy and reliable policies to support young girls who are at greater risk of undergoing early marriage and sexual harassment. Educational campaigns require to promote public knowledge regarding reproductive health and contraception. Moreover, women empowerment, technical and financial aid to distressed and victimised women, and proper pedagogy on the mental and physical implications of underage marriage must be emphasised urgently to curb this child marriage syndemic during the COVID-19 pandemic era.

\section{PATIENT AND PUBLIC INVOLVEMENT}

Patients and/or the public were not involved in the design, or conduct, or reporting, or dissemination plans of this research.
Contributors MJH conceived the idea and collected data. MJH and MAS drafted the original version of the manuscript. MJH, MSB, TBE and MRI critically reviewed the manuscript. All authors reviewed and approved the final version of the manuscript for publication.

Funding The authors have not declared a specific grant for this research from any funding agency in the public, commercial or not-for-profit sectors.

Competing interests None declared.

Patient consent for publication Not required.

Provenance and peer review Not commissioned; externally peer reviewed.

Open access This is an open access article distributed in accordance with the Creative Commons Attribution Non Commercial (CC BY-NC 4.0) license, which permits others to distribute, remix, adapt, build upon this work non-commercially, and license their derivative works on different terms, provided the original work is properly cited, appropriate credit is given, any changes made indicated, and the use is non-commercial. See: http://creativecommons.org/licenses/by-nc/4.0/.

ORCID iDs

Md. Jamal Hossain http://orcid.org/0000-0001-9706-207X

Talha Bin Emran http://orcid.org/0000-0003-3188-2272

\section{REFERENCES}

1 Afrin T, Zainuddin M. Spike in child marriage in Bangladesh during COVID-19: determinants and interventions. Child Abuse Negl 2021;112:104918.

2 Dhaka Tribune. 6,500 Rajshahi students became child brides amid pandemic. Available: https://www.dhakatribune.com/bangladesh/ nation/2021/10/20/6-500-rajshahi-students-became-child-bridesamid-pandemic [Accessed 20 Oct 2021].

3 Dhaka Tribune. Child marriage up 13\% during Covid-19 pandemic in Bangladesh. Available: https://www.dhakatribune.com/bangladesh/ law-rights/2021/03/28/child-marriage-up-13-during-covid-19pandemic-in-bangladesh [Accessed 1 Sep 2021].

4 Roy P, Basher M. Child marriage in pandemic: a scourge returns on tiptoe. Daily Star. Available: https://www.thedailystar.net/news/ bangladesh/news/child-marriage-pandemic-scourge-returns-tiptoe2195446 [Accessed 26 Oct 2021].

5 Asia-Pacific. Child marriages become epidemic during pandemic in Bangladesh. Available: https://www.aa.com.tr/en/asia-pacific/ child-marriages-become-epidemic-during-pandemic-in-bangladesh/ 2396364 [Accessed 20 Oct 2021].

6 Islam MR, Hossain MJ. Increments of gender-based violence amid COVID-19 in Bangladesh: A threat to global public health and women's health. Int J Health Plann Manage 2021;17:2436-40. 